\title{
Pengaruh Terapi Pijat Terhadap Kenaikan Berat Badan Bayi Prematur di RSUP. Dr. M. Djamil Padang
}

\author{
Yori Rahmi ${ }^{a}$, Wedya Wahyu ${ }^{\text {b }}$ Eliza Anas $^{c}$ \\ ${ }^{a}$ RSUP Dr.M.Djamil Padang \\ b Progam Studi Ilmu Keperawatan Universitas Andalas \\ ${ }^{\mathbf{c}}$ Fakultas Kedokteran Universitas Andalas
}

\begin{abstract}
Prematurity had a very high risk in mortality of infants. An infant born with pregnancy periode less than 37 weeks and had body weight as gestation period was called by prematurity or else less months neonates. Premature infant often experienced a low body weight problem. Stimulation was needed in raising the body weight of premature infant. One of the non invansif actions that encouraged in increasing the weight was massage therapy. Massage, accorded to the American Association of Massage Therapy (AMTA) was defined as the manipulation of soft tissue by using hand or body to hold, move or give stressing on body manually. The research focused on knowing the influence of message therapy to the raising of the body weight of premature infant in $d r$. M. Djamil Padang. The research had been held on March to April 2012 on 18 of stable premature infants. This research had been using the preexperimental one group pretest posttest measurement. It had been done by recorded the body weight of infant before and after message therapy was applied for 5 days. T-Test dependent (paired t-test) was used for statistic test result. Statistic test result with bivariate analysis showed that there was a body weight changing $(p=0.000)$. It meaned that massage therapy affected the raising of the body weight of premature infant.
\end{abstract}

Key words: body weight, prematurity, massage therapy

\begin{abstract}
Abstrak: Prematuritas merupakan penyumbang angka kematian bayi yang cukup tinggi. Prematuritas adalah bayi lahir dengan masa kehamilan < 37 minggu dan berat badan sesuai dengan masa gestasi tersebut atau disebut juga neonatus kurang bulan. Bayi prematur sering mengalami masalah akibat berat badan rendah. Diperlukan stimulasi yang dapat membantu dalam meningkatkan berat badan bayi prematur. Salah satu tindakan non invansif yang menyokong peningkatan berat badan adalah terapi pijat. Pijat atau massage menurut American Association of Massage Therapy (AMTA) didefinisikan sebagai manipulasi pada jaringan lunak yang dilakukan secara manual dengan menggunakan tangan atau tubuh untuk memegang, menggerakkan, dan atau memberikan penekanan pada tubuh. Penelitian ini bertujuan mengetahui pengaruh terapi pijat terhadap kenaikan berat badan bayi prematur di RSUP dr. M. Djamil Padang. Penelitian ini dilakukan dari bulan Maret sampai April 2012 terhadap 18 bayi prematur stabil. Penelitian ini menggunakan rancangan pre experimental one group pretest-posttest. Pengukuran ini dilakukan dengan mencatat berat badan bayi sebelum dilakukan terapi pijat dan berat badan setelah 5 hari berturut-turut dilakukan terapi pijat. Hasil uji statistik yang digunakan adalah T-Test dependent (paired $t$-test). Hasil uji statistik dengan analisa bivariat menunjukkan terdapat perubahan berat badan yang bermakna $(p=0,000)$. Hal ini berarti bahwa terapi pijat berpengaruh dalam meningkatkan berat badan bayi prematur.
\end{abstract}

Kata kunci: berat badan, prematur, terapi pijat. 
Kelahiran prematur merupakan beban bagi orang tua. Mereka biasanya akan terlihat shock, tidak dapat menerima sering muncul ini dapat menetap lama setelah bayi prematur lahir. Munculnya rasa penerimaan atas kelahiran yang prematur dari para orang tua memang berbeda-beda waktunya, tetapi umumnya sebagian besar akan dapat menerima keadaan ini dan mulai untuk mencari jalan bagi menolong bayinya (Rusli U, 2007).

Prematuritas dan berat badan lahir rendah merupakan suatu keadaan yang sangat terkait dengan berbagai macam komplikasi yang dapat mengancam kehidupan bayi baru lahir serta menimbulkan gangguan neurologi dan perkembangan yang berbanding terbalik dengan usia kehamilan dan berat badan lahir (Bhutta, 2002). Bayi prematur yang lahir sebelum waktunya akan mengalami trauma yang lebih berat lagi. Bayi prematur akan merasa seorang diri dalam ruang incubator (isollete), dirawat oleh orang-orang asing dan umumnya sentuhan yang dialaminya ialah sentuhan negatif atau sentuhan yang menyakitkan. Sentuhan-sentuhan itu di antaranya pengambilan darah yang berulang, pemasangan alat-alat monitor, infus, pemasangan NGT (Naso Gastric Tube: selang yang dimasukkan dari hidung ke lambung) dan kateter intravena (Field TM, 2003).

Prematuritas merupakan penyumbang angka kematian bayi yang cukup tinggi. Kelahiran dengan usia gestasi 32-36 minggu terjadi pada kurang lebih $5 \%$ persalinan dengan angka kematian neonatal $15 \%$, sedangkan kelahiran dengan usia gestasi $\leq 32$ minggu hanya terjadi sekitar $1 \%$ persalinan, namun angka kematiannya sangat tinggi (45\%). Diperkirakan sekitar 12\% kelahiran di Amerika Serikat merupakan kelahiran prematur dan $8 \%$ mempunyai berat badan lahir rendah (Field, 2004). Asfiksia, infeksi neonatal, gangguan metabolik dan kestabilan suhu, semua gangguan yang berhubungan dengan belum matangnya keadaan, merasa bersalah, marah, depresi dan takut. Perasaan-perasaan negatif yang

organ-organ vital seperti penyakit membran hialin dan beberapa kelainan lainnya dapat meningkatkan risiko morbiditas dan mortalitas bayi prematur (Bhutta, 2002).

Selama beberapa tahun terakhir, rata-rata kematian bayi (IMR) di Indonesia telah menurun hingga 35 dari 1000 kelahiran pada tahun 2002-2003. Barubaru ini Jalal $\mathrm{F}$ dalam pidato pengukuhan guru besarnya juga menyampaikan bahwa prevalensi BBLR di Indonesia pada tahun 2007 masih cukup tinggi, yaitu 11,5\% dengan sebaran yang cukup bervariasi pada masing-masing provinsi. Angka terendah tercatat di Bali $(5,8 \%)$ dan tertinggi di Papua (27\%), sedangkan Provinsi Sumatera Barat berkisar 7\% (Jalal, 2009).

Penatalaksanaan yang optimal terhadap bayi prematur atau berat badan lahir rendah terbukti efektif menurunkan angka kematian dan kesakitan bayi prematur, namun prosedurnya cukup kompleks dan memakan biaya yang tidak sedikit. Berbagai intervensi terhadap bayi prematur mulai dikembangkan untuk dapat memacu pertumbuhan dan perkembangannya dan mempersingkat masa rawatan. Stimulasi taktil, kinestetik, vestibuler, oral, auditorius dan kombinasi stimulasi lainnya diperlukan untuk perkembangan ekstrauterin bayi prematur serta membantu bayi beradaptasi terhadap lingkungan ekstrauterin (Field TM dkk, 2004).

Perawatan bayi prematur dan berat badan lahir rendah di NICU Amerika Serikat rata-rata membutuhkan waktu 3 minggu dengan perkiraan biaya 1000 sampai 2500 dolar Amerika per pasien per hari. Untuk mereduksi biaya ini, para ahli mulai mengembangkan beberapa intervensi terhadap bayi prematur agar dapat memacu pertumbuhan dan perkembangan sehingga dapat memperpendek lama rawatan dan 
mengurangi biaya perawatan di rumah sakit. Salah satu stimulasi yang banyak dikembangkan adalah pijat bayi (Field TM, 2008).

Beberapa penelitian sudah membuktikan bahwa bayi prematur yang dipijat akan mengalami peningkatan berat badan yang lebih besar (47\%) serta mempunyai masa rawatan lebih pendek berkisar antara 3-6 hari lebih cepat keluar dari rumah sakit dibandingkan dengan kelompok kontrol sehingga dapat menghemat biaya 10.000 dolar Amerika per bayi (Field TM, 2004).

Studi tentang mekanisme efek pijat bayi terhadap perubahan fisiologikal dan biokimiawi untuk meningkatkan pertumbuhan, meliputi peningkatan aktivitas vagus yang selanjutnya akan mempengaruhi pelepasan hormon pencernaan seperti gastrin, insulin dan Insulin-growth factor (IGF-1) serta meningkatkan efisiensi proses metabolik tubuh (Gunardi H, 2002). Efek lain dari terapi pijat adalah berkurangnya tingkat stres bayi terbukti dengan berkurangnya hormon stres (kortisol, adrenalin dan noradrenalin), membuat bayi tidur lebih lelap serta meningkatkan hubungan (bonding) ibu dan anak (Rosalina I, 2007).

Pijat bayi sebenarnya telah dipraktekkan secara luas di dunia termasuk Indonesia. Seni pijat diajarkan secara turun-temurun walaupun pada awalnya tidak diketahui secara jelas bagaimana pijat dan sentuhan dapat berpengaruh demikian positif pada tubuh manusia (Roesli U, 2007).

Rumah sakit umum pusat Dr. M. Djamil Padang merupakan rumah sakit rujukan yang mampu merawat bayi dan neonatus yang mempunyai berbagai masalah umum bayi risiko tinggi termasuk bayi berat badan lahir rendah. Data bulan Januari 2010 sampai dengan Desember 2010 menunjukkan jumlah angka bayi prematur yang dirawat di perinatologi RSUP DR. M. Djamil Padang ada 231 orang, sedangkan pada bulan Januari sampai dengan Desember 2011 ada 261 orang (Medical Record dan buku register/ laporan RSUP dr. M. Djamil Padang ).

Wawancara dengan Ardawiza, perawat bangsal anak di bagian perinatologi dengan peneliti yang dilakukan pada tanggal 12 februari 2011 menyatakan bahwa ada beberapa hal yang penting diketahui mengenai bayi prematur selama masa rawatan: lama hari rawat, komplikasi masa rawatan dan peningkatan berat badan bayi prematur perhari. Ardawiza menyatakan bahwa bayi prematur yang dirawat dengan tanpa komplikasi yang memiliki berat badan 1500 gram rata-rata mempunyai masa rawatan lebih kurang 2 minggu, sedangkan bayi dengan berat badan $\geq 1800$ gram ratarata mempunyai masa rawatan lebih kurang 1 minggu.

Berdasarkan wawancara dengan penanggung jawab sub bagian perinatologi dr. Eni Yantri, SpA. dengan peneliti yang dilakukan pada tanggal 17 Februari 2011 menyatakan bahwa terdapat beberapa standar untuk pemulangan bayi prematur diantaranya: memiliki berat badan $\geq 1800$ gram, bisa minum, berat badan meningkat sesuai grafik, pertumbuhan normal, tidak ada penyakit dasar dan ibu percaya diri untuk membawa bayinya pulang. Dr. Eni Yantri menyatakan bahwa peningkatan berat badan bayi rata-rata perhari $20-30 \%$ selama masa perawatan sedangkan pada bayi dengan komplikasi peningkatan berat badan tergantung respon dari bayi tersebut.

Berdasarkan studi pendahuluan yang peneliti lakukan di perinatologi pada tanggal 2 Maret 2011 bahwa 5 dari 7 orang bayi prematur yang dirawat dengan komplikasi rata-rata kenaikan berat badan sekitar 10-15 gram perhari, dengan lama rawatan sekitar 20-25 hari dan biaya perawatan perhari sekitar $\pm 500.000,-$. Selama ini tindakan perawatan yang dilakukan terhadap bayi prematur tersebut yakni dengan minimal touch atau minimal handling, serta kanggoroo care yang juga berpengaruh terhadap peningkatan berat badan bayi prematur tersebut. 
Komplikasi yang terjadi selama masa rawatan pada bayi prematur diantaranya: sepsis, retinopati pada bayi prematur (ROP), anemia pada bayi prematur, osteopeni pada bayi prematur, nec, periventiculo leukomalasia (PVL) dan perdarahan intracerebral(Lissaver $\mathrm{T}$, 2011).

Penelitian tentang pijat bayi sebagian besar dikembangkan di negara maju seperti Amerika dan Eropa, hanya sebagian kecil negara Asia memberi perhatian tentang pijat bayi ini, terutama Indonesia. Ikatan Dokter Anak Indonesia cabang Sumatera Barat sampai saat ini

\section{METODE}

Penelitian ini merupakan suatu penelitian pra eksperimen design dengan rancangan "one group pretest-postest" (Notoadmodjo, 2005). Ciri tipe penelitian ini adalah mengungkapkan hubungan sebab akibat dengan cara melibatkan satu belum merekomendasikan pijat bayi sebagai program penunjang stimulasi bayi, terutama bayi prematur dan berat badan lahir rendah. Belum pernah dilakukan penelitian tentang stimulasi pijat pada bayi di lingkungan rumah sakit, sehingga program ini juga belum begitu familier, baik di lingkungan petugas maupun orang tua.

Berdasarkan hal tersebut di atas peneliti tertarik untuk melakukan penelitian tentang pengaruh terapi pijat terhadap kenaikan berat badan bayi premature di RSUP DR. M. Djamil Padang.

kelompok subjek (Nursalam, 2009). Teknik pengambilan sampel dalam penelitian ini adalah non probability sampling yaitu total sampling. Jumlah sampel dalam penelitian ini adalah 18 orang bayi.

\section{HASIL DAN PEMBAHASAN}

Tabel 5.1.

Karakteristik dasar bayi berdasarkan jenis kelamin dan paritas di RSUP DR. M. Djamil Padang Tahun 2012

\begin{tabular}{lccc}
\hline & & Frekuensi & Persentase \\
& & $(\mathbf{N})$ & $\%$ \\
\hline Jenis Kelamin & Perempuan & 11 & $\mathbf{6 1 , 1}$ \\
Lnak Ke & Laki-laki & 7 & $\mathbf{3 8 , 9}$ \\
& 1 & 5 & $\mathbf{2 7 , 8}$ \\
& 2 & 10 & 55,6 \\
& 3 & 1 & 5,6 \\
& 4 & 1 & 5,6 \\
& 5 & 0 & 0,0 \\
& 6 & 1 & 5,6 \\
\hline
\end{tabular}

Pada table 5.1 menunjukkan bahwa dari 18 responden terdiri dari 11 orang $(61,1 \%)$ berjenis kelamin perempuan dan 7 orang $(38,9 \%)$ berjenis kelamin laki-laki. Paritas terbanyak adalah anak kedua 11 orang $(61,1 \%)$, sedangkan paritas yang paling sedikit anak ketiga, keempat dan keenam yang masing-masing 1 orang $(5,6 \%)$. 
Tabel 5.2.

Karakteristik Orang Tua Bayi berdasarkan pendidikan ibu, pekerjaan ibu, status gizi ibu, pendidikan ayah, pekerjaan ayah di RSUP DR. M. Djamil Padang Tahun 2012

\begin{tabular}{llcc}
\hline \multicolumn{1}{c}{ Karakteristik Orang Tua } & \multicolumn{1}{c}{ Kriteria } & F & \% \\
& SD & 1 & 5,6 \\
Pendidikan Ibu & SMP & 1 & 5,6 \\
& SMA & 11 & 61,1 \\
& PT & 5 & 27,8 \\
Pekerjaan Ibu & Tidak bekerja & 11 & 61,1 \\
& Bekerja & 7 & 38,9 \\
Status gizi ibu & Baik & 16 & 88,9 \\
& Kurang & 2 & 11,1 \\
Pendidikan Ayah & SMP & 2 & 11,1 \\
& SMA & 9 & 50 \\
& PT & 7 & 38,9 \\
Pekerjaan Ayah & Buruh/tani & 2 & 11,1 \\
& Swasta & 11 & 61,1 \\
& PNS & $\mathbf{5}$ & $\mathbf{2 7 , 8}$ \\
\hline
\end{tabular}

Tabel $5.2 \quad$ memperlihatkan karakteristik orang tua bayi dari 18 orang tua bayi responden penelitian. Pendidikan orang tua terbanyak adalah Sekolah Menengah Atas, yaitu 11 (61,1 \%), sebagian besar (lebih dari $60 \%$ ) ibu mempunyai status gizi baik dan berstatus sebagai ibu rumah tangga. Ayah umumnya memiliki pekerjaan swasta, yaitu 11 (61,1\% bahkan lebih dari separuhnya), 2 orang $(11,1 \%)$ berprofesi buruh/tani dan $5(27,8 \%)$ berprofesi sebagai PNS.

Tabel 5.3.

Distribusi rata-rata berat badan bayi sebelum dan sesudah dilakukan terapi pijat di RSUP DR. M. Djamil Padang Tahun 2012

\begin{tabular}{|c|c|c|c|}
\hline $\begin{array}{l}\text { Berat badan } \\
\text { sebelum (gr) }\end{array}$ & $\begin{array}{l}\text { Berat badan } \\
\text { sesudah (gr) }\end{array}$ & $\begin{array}{c}\begin{array}{c}\text { Kenaikan BB } \\
\text { (gr) }\end{array} \\
\end{array}$ & Distribusi \\
\hline 1512 & 1612 & 100 & Pre Intervensi \\
\hline 1597 & 1739 & 142 & Mean : 1692,17 \\
\hline 1742 & 1864 & 122 & SD $\quad: 145,82$ \\
\hline 1682 & 1817 & 135 & Max : 1997 \\
\hline 1549 & 1659 & 110 & Min : 1512 \\
\hline 1537 & 1662 & 125 & \\
\hline 1541 & 1636 & 95 & Post Intervensi \\
\hline 1654 & 1782 & 128 & Mean : 1804,22 \\
\hline 1585 & 1720 & 135 & SD $: 144,27$ \\
\hline 1693 & 1768 & 75 & Max : 2097 \\
\hline 1576 & 1676 & 100 & : 1612 \\
\hline 1656 & 1756 & 100 & \\
\hline 1948 & 2068 & 120 & Kenaikan BB \\
\hline 1997 & 2097 & 100 & Mean : 112,05 \\
\hline 1715 & 1815 & 100 & SD $\quad: 19,99$ \\
\hline 1823 & 1953 & 130 & Max : 142 \\
\hline 1754 & 1879 & 125 & : 75 \\
\hline 1898 & 1973 & 75 & \\
\hline
\end{tabular}


Dari Tabel 5.3 menunjukkan nilai tendensi sentral berat badan bayi sebelum dilakukan terapi pijat adalah $1692,17 \mathrm{gr}$, dengan sebaran nilai berat badan bayi yaitu $145,82 \mathrm{gr}$, dimana berat badan yang paling ringan 1512 gr dan yang paling berat 1997 gr. Sedangkan nilai tendensi sentral berat badan bayi prematur di Perinatologi RSUP. dr. M. Djamil Padang sesudah 5

\section{Analisa Bivariat}

Setelah diolah dengan analisa univariat, data selanjutnya diolah dengan analisa bivariat. Sebelum pengujian hipotesa dilakukan, terlebih dahulu data dilakukan uji normalitas data. Syarat Uji Normalitas menurut Dahlan (2008) ada 2 metode yaitu metode deskriptif dan metode analitis. Hasil uji normalitas data secara analitis dengan Shapiro-Wilk (lima) hari berturut-turut dilakukan terapi pijat adalah 1804,22 gr, dengan sebaran nilai berat badan bayi yaitu 144,27 gr, dimana berat badan yang paling ringan 1612 gr dan yang paling berat 2097 gr. Pada kenaikan berat badan bayi yang paling ringan sebanyak 75 gram dan yang paling berat 142 gram.

didapatkan $\mathrm{p}$ value $>0,05$ sehingga dapat disimpulkan bahwa distribusi data normal. Karena data berdistribusi normal maka uji hipotesis yang dipakai adalah uji t_test dependen. Hal ini bertujuan untuk melihat apakah ada kenaikan berat badan setelah diberikan terapi pijat selama 5 (lima) hari berturut-turut.

Tabel 5.4 : Perubahan Berat Badan Bayi Prematur yang Dilakukan Terapi Pijat di RSUP. dr. Djamil Padang Tahun 2012

\begin{tabular}{lccccc}
\hline & Mean & SD & \multicolumn{2}{c}{ 95 \% CI } & P Value \\
\cline { 5 - 5 } Berat Badan & 112,05 & 19,99 & 121,99 & 102,11 & 0,000 \\
\hline
\end{tabular}

Tabel 5.3 diketahui bahwa terjadi peningkatan rata-rata berat badan 112,05 gr dengan standar deviasi 19,99 setelah dilakukan terapi pijat. Hasil uji statistic dengan $\mathrm{p}=0,000 \quad(\mathrm{p}<0,05)$ yang artinya

Penelitian yang dilakukan terhadap bayi prematur di Perinatologi RSUP. DR. M. Djamil Padang yang terdiri dari 18 orang bayi prematur sebagai responden, dimana berat badan bayi prematur sebelum dilakukan terapi pijat yang paling tinggi adalah 1997 gr dan yang paling rendah 1512 gr. Rata-rata berat badan bayi sebelum dilakukan terapi pijat adalah $1692,17 \mathrm{gr}$.

Menurut WHO (dikutip dari Surasmi, dkk: 2003) semua bayi baru lahir yang berat badannya kurang atau sama dengan 2500 gram disebut BBLR (berat secara signifikan terdapat pengaruh terapi pijat dalam meningkatkan berat badan bayi prematur.

badan lahir rendah). Bayi kurang bulan adalah bayi yang belum matur, sehingga belum dapat beradaptasi dengan sempurna pada kehidupan neonatal.

Bayi perempuan lebih banyak dibandingkan dengan bayi laki-laki $(61,1 \%$ vs 38,9\%), hasil ini tidak sama dengan penelitian Dieter dkk (2001), kecuali paritas (terbanyak adalah anak ke 2 baik pada kelompok pijat maupun kelompok kontrol), begitu juga dengan penelitian ini dimana berasal dari keluarga dengan sampel sebagai anak kedua.

Ditemukannya berat badan bayi dengan rata-rata berat badan 1692,17 
gram dengan usia 10 hari disebabkan beberapa faktor diantaranya karena intervensi maupun pengamatan dimulai pada hari ke 10 kelahiran dimana secara fisiologis (untuk bayi prematur) anak mengalami kehilangan berat badan. Bayi baru lahir akan mengalami kehilangan berat badan secara fisiologis pada minggu pertama karena kehilangan cairan ekstraseluler (pada bayi cukup bulan sebesar 5$10 \%$ ) dan mencapai 2 minggu pada bayi prematur dengan prosentasi yang lebih besar (mencapai 15\%). Kehilangan berat badan ini biasanya terjadi pada hari ke 4-6.

Disini sangat penting peran perawat anak untuk mengidentifikasi penyebab terjadinya penurunan berat badan bayi prematur, sehingga dapat meminimalkan kejadian penurunan berat badan bayi.

Pada penelitian ini secara uji statistik terdapat perbedaan yang signifikan antara berat badan bayi sebelum dilakukan terapi pijat degan berat badan bayi setelah dilakukan terapi pijat, dimana terjadi peningkatan rata-rata berat badan 112,05 gr untuk masing-masing bayi (berdasarkan tabel 5.3) . Lebih kecilnya pertambahan berat badan dibanding penelitian lain, mungkin dapat disebabkan adanya kelainan penyerta dan fasilitas tempat perawatan bayi prematur.

Semua bayi secara rata-rata mengalami kenaikan berat badan, namun terdapat perbedaan besarnya kenaikan berat badan setelah dilakukan terapi pijat selama 5 hari berturut-turut, dalam penelitian ini terdapat satu orang bayi yang mengalami kenaikan berat badan sebesar 142 gr dimana bayi tersebut tidak mempunyai kelainan penyerta dan dirawat karena merupakan bayi prematur murni yang memerlukan perawatan dalam incubator. Terdapat 2 orang bayi yang hanya mengalami kenaikan berat badan sebesar 75 gram salah satu faktornya karena proses penyakit yang dialami bayi sebelum terjadi kondisi hemodinamik yang stabil sehingga dapat dilakukan terapi pijat dan faktor psikologis yang dialami oleh ibu bayi sehingga mempengaruhi volume produksi ASI yang sangat dibutuhkan terutama untuk bayi prematur.

Penelitian yang dilakukan Lahat dkk mendapatkan bahwa pengeluaran energi pada bayi prematur yang stabil secara signifikan lebih rendah setelah 5 hari menjalani terapi pemijatan. Penurunan pengeluaran energi ini merupakan salah satu mekanisme peningkatan pertumbuhan pada pemijatan pada kondisi medis bayi prematur yang stabil.

Penelitian didukung oleh penelitian yang dilakukan Prof. T. Field dan Scafidi (1986 dan 1990) menunjukkan bahwa pada 20 bayi prematur (dengan rata-rata berat badan lahir 1280 gr dan rata-rata rawatan di NICU selama 20 hari sebelm intervensi), yang dipijat selama $3 \times 15$ menit selama 10 hari, mendapatkan pertambahan berat badan 25 gram/hari dan 17 gram/hari pada kelompok pijat dan kontrol secara beturut-turut (20\%-47\% per hari).

Hasil penelitian Dieter dkk (2001) mendapatkan total pertambahan berat badan 53\% lebih besar pada kelompok pijat yakni 243,5 gram (48,7 gram/hari) dan 113,5 gram $(22,7$ gram/hari pada kelompok kontrol). Kedua penelitian diatas mendapatkan pertambahan berat badan yang lebih besar pada kedua kelompok, hal ini mungkin disebabkan karena pada penelitian Field maupun Dieter dkk, penelitian dilakukan setelah bayi melewati kehilangan berat badan fisiologis, rata-rata setelah mulai minggu ke 3 dan ke 4 sehingga pertambahan berat badan menjadi lebih nyata.

Hasil penelitian dengan uji dua rerata berpasangan (t-test dependen) didapatkan hasil uji statistik dimana nilai $\mathrm{p}=0,000$ $(\mathrm{p}<0,05)$. Sesuai dengan aturan keputusan hipotesis statistik berarti Ha diterima dan Ho ditolak, berarti terlihat adanya 
pengaruh terapi pijat terhadap kenaikan berat badan bayi prematur.

Berbagai faktor dapat mempengaruhi kenaikan berat badan bayi dari hari ke hari, Berdasarkan hasil penelitian diatas bahwa proses ASI merupakan salah satu faktor penting. ASI dari ibu yang melahirkan secara prematur mengandung energi, protein dan lemak dalam kadar yang lebih tinggi dengan kadar tertinggi pada hari ke 8-11 untuk ASI. Perubahan frekuensi dan lama menyusui yang terjadi setelah bayi dipijat dapat ditemukan pada penelitian ini sehingga semakin sering dan lama bayi yang dipijat menyusu pada ibunya , akan menunjang kenaikan berat badan selama bayi berada dalam kondisi sehat.

Penelitian Field dkk (2005) membuktikan bahwa kenaikan barat badan bayi yang mendapat pijat antara lain disebabkan oleh meningkatnya aktivitas vagal yang merangsang sekresi insulin, gastrin dan IGF-1. Faktor-faktor ini sudah diketahui sebagai faktor yang berperan pada pertambahan berat badan neonatus.

\section{KESIMPULAN DAN SARAN}

Berdasarkan hasil penelitian yang dilakukan tentang pengaruh terapi pijat terhadap kenaikan berat badan bayi premature di RSUP DR. M. Djamil Padang Tahun 2012 maka dapat diambil kesimpulan adanya pengaruh yang signifikan terhadap kenaikan berat badan bayi prematur yang dilakukan terapi pijat.

Terapi pijat sebaiknya dilakukan pada bayi prematur stabil di ruangan perinatologi untuk memacu peningkatan berat badan sebagai bentuk optimalisasi tumbuh kembang sejak awal kehidupan.

Dilakukan penelitian keperawatan lebih lanjut agar dapat meningkatkan berat badan bayi prematur dengan jumlah sampel yang lebih besar dan waktu yang lebih lama terhadap variable yang tidak diuji pada penelitian sehingga diharapkan terapi pijat ini lebih dapat diterima sehingga penerapannya dapat lebih dioptimalkan.

\section{DAFTAR PUSTAKA}

Bhutta AT, Cleves MA, Casey PH, Cradock MM, Anand KJ. (2002). Cognitif and Behavioral Outcomes of scholl-aged children who were born preterm. Journal of the American Medical Association, 288, 728-37.

Field TM. (2008). Stimulation of preterm infant. Diakses pada tanggal $22 \mathrm{Mei}$ 2011 dari http//www.pedsinreview.aapublicati ons.org.id.

Field TM. (2004). Touch therapy effects on development. International Journal of Behavioral Development. Diakses pada tanggal 22 Mei 2011 dari: http//www.jbd.sagepub.com.

Field TM. (2003). Stimulation of preterm infant. Diakses pada tanggal $22 \mathrm{Mei}$ 2011, dari http//pedsinreview.aapublications.or g.

Field TM, Hernandez-Reif M, Freedman J. (2004). Stimulation programs for preterm infant. Social Policy Report 2004,18(1) 3-14.

Field TM, Schanber SM. (2008). Tactile/kinesthetic stimulation effect on preterm neonates. Diakses pada tanggal 22 Mei 2011 dari $\mathrm{http} /$ /www.pediatrics.org.id. [

Gunardi, H. (2002). Pemantauan Bayi Prematur. Dalam: Trihono PP,Purnamawati S, Syarif DR, Hegar B, Gunardi H, Oswari H, Kadim M, penyunting. Hot Topics in Pediatrics II. Jakarta: Balai Penerbit FKUI; 2002.h.17-27

Jalal F. (2009) Pengaruh Gizi dan Stimulasi Psikososial terhadap Pembentukan Kecerdasan Anak Usia Dini: Agenda Pelayanan Tumbuh Kembang Anak Holistik-Integratif. Pidato Pengukuhan Guru Besar 
Tetap dalam Bidang Ilmu Gizi Pada Fakultas Kedokteran Universitas Andalas. Disampaikan pada Rapat Senat Luar Biasa Padang, 25 April 2009.

Notoadmodjo, S. (2005). Metodologi penelitian kesehatan (Edisi 3). Jakarta: Rineka Cipta.

Nursalam. (2008). Konsep dan penerapan metodologi penelitian ilmu keperawatan, Pedoman Skripsi, Tesis, Dan Instrumen Penelitian Keperawatan. Jakarta: Salemba Medika.

Roesli U. (2007). Pedoman pijat bayi prematur dan bayi usia 0-3 bulan. Jakarta: Trubus Agriwidya. 2-41.

Rosalina I. (2007). Fisiologi pijat pada bayi. Bandung: Trikarsa Multi Media. 2-31. 